\title{
Impoliteness and Threat Responses in an Iraqi-Kurdish EFL Context
}

\author{
Shurooq A. Ali \\ Department of English, College of Arts \\ University of Baghdad, Iraq
}

Received: 4/12/2021

Accepted: 5/19/2021

Published:6/24/2021

\begin{abstract}
This study shows impoliteness as a form of face-threatening that can be intentionally caused by verbal threats in a particular setting. It investigates: what strategies and mitigators do IraqiKurdish English as a foreign language (EFL) learners use in situations of threat responses? The present investigation paper aims to examine impoliteness strategies and mitigators by these learners when they respond to threatening situations in their context. Thus, it fills a gap in pragmatics literature by investigating the reactions to threats in an Iraqi-Kurdish EFL context. To this end, 50 participants have participated in this study. An open-ended questionnaire in the form of a Discourse Completion Task (DCT) is used to elicit responses from the participants. Besides, a focus group interview is conducted to support the data analysis. The data are coded based on Limberg's (2009) model of impoliteness and threat responses to figure out the strategies used by the learners. Blum-Kulka, House, and Kasper's (1989) taxonomy of mitigators is adapted to analyze the mitigators. Overall, the findings reveal that the preferred responses surpass those which indicate dispreference by the learners. They tend to use face-saving acts when they comply with the threatener's demand and opt for face-threatening acts when they reject that demand indirectly. Moreover, these learners use mitigators to attenuate the illocutionary force of their responses. Finally, this study provides some recommendations and pedagogical implications.
\end{abstract}

Keywords: Impoliteness, Iraqi-Kurdish EFL context, mitigators, responses to threats, social power

Cite as: Ali, S. A. (2021). Impoliteness and threat responses in an Iraqi-Kurdish EFL context. Arab World English Journal, 12(2), 31-48.

DOI: https://dx.doi.org/10.24093/awej/vol12no2.3 


\section{Introduction}

The issue of face attack and how the addressee responds to it should be taken into account because it is one aspect of impoliteness that causes conflict. Threats do not only threaten the addressee's face but rather the speaker's face can also be damaged by verbal threats in case the hearer does not comply with the desired action or replies aggressively. A threat can be viewed as a communicative strategy by which the threatener intentionally uses it to create conflict with the addressee. This act possibly creates an extreme procedure of impolite behavior and can be used as a face-threatening strategy that intentionally aims to ensure hearers' compliance in a particular context. For doing so, the addressee faces negative consequences in case s/he does not show cooperation. The threat can be considered an impolite behavior in two ways: (i) the threatener intentionally initiates it regardless of the target's face concerns, and (ii) both interlocutors interactively create impoliteness in a particular setting although one speaker produces the threat (Limberg 2009).

Due to the issue that threats are like an inherent aggressive social activity (Geluykens \& Limberg, 2012) and they intrinsically threaten the hearer's negative and positive face, they are deemed as face-threatening acts (Brown \& Levinson, 1987). They are illocutionary acts (Fraser, 1975) and essentially impolite (Leech, 1983). They are ferocious and rude in their nature unless they are utilized facetiously (Harris, 1984).

The current study fills a gap in pragmatics literature by investigating impoliteness in response to threatening situations in a new EFL context not examined before (i.e., Iraqi-Kurdish EFL context). Following Limberg's (2009) research, this study examines impoliteness strategies and mitigators by Iraqi-Kurdish EFL learners when they respond to threatening situations performed intentionally in their context. The current research focuses not only on the threat as one of the speech acts but rather on the sequence that consists of a threat and the response it follows in real-life situations. It seeks answers to the following research questions:

1. What strategies do Iraqi-Kurdish EFL learners use in situations of threat responses?

2. What mitigators do Iraqi-Kurdish EFL learners use in situations of threat responses?

\section{Literature Review}

Interlanguage pragmatics is concerned with using the target language by non-native speakers (Félix-Brasdefer, 2017). It is a subfield of interlanguage research investigating the production and perception of speech acts by second language learners in a target setting (Schauer, 2009). The main framework in interlanguage pragmatics is represented by speech act theory (Félix-Brasdefer, 2017). The theory of speech acts is originated by Austin (1962) and developed by Searle $(1969,1979)$. Austin (1962) found out that we do things verbally when we produce words. One major thing we do via means of language is to try to affect people into actions that suit them, us, or both of us (Pérez-Hernández, 2021). The theory of speech acts focuses on the difference between 'illocutionary force' and 'propositional content.' Every speech act can be analyzed into force and content which differ separately from one another (Hanks, 2018). The speech act is a substantial part of pragmatics, which focuses on the intended meaning of an utterance (Cutting, 2002; Fairclough, 1989). However, Leech (1983) and Thomas (1983) proposed two salient concepts of pragmatics: pragmalinguistics and sociopragmatics. The former is concerned with the particular linguistic resources that language users have in a specific context for convening particular illocutions. The latter refers to knowledge about the social norms in 
specific situations and how the speakers properly utilize the linguistic resources in a second language social setting (Barron, 2003; Félix-Brasdefer, 2017; Leech, 1983).

Based on Oxford English Dictionary (OED Online) (2020), a threat is defined as "a declaration of hostile determination or of loss, pain, punishment, or damage to be inflicted in retribution for or conditionally upon some course." In addition, the act of threatening is welldefined as the act that is performed to pressure, urge, and convince someone via means of menaces.

Some approaches are closely developed by Fraser (1998) and Storey (1995) after proposing the 'felicity conditions' by Searle (1969). The illocutionary act of threatening is defined by Fraser (1998) as that one performed intentionally by a speaker via an utterance under three conditions: (1) the speaker aims to commit the act intentionally, (2) the speaker believes that the addressee will face unwanted consequences, and (3) the speaker's purpose is to frighten the addressee by making him/her aware of the aim in the first condition.

In the same vein, Storey (1995) illustrated three basic types of threats: (1) 'warning threats,' which notify the addressee of probable consequences of specific performance, but are eventually to the addressee's advantage, (2) 'pure threats,' which help the speaker by forcing the addressee to perform something, and (3) 'frightening threats,' which can be used for the same purpose of the latter type, but no coercion is included.

It is worth mentioning that the addressee uses threats when s/he performs an improper behavior. This behavior either influences the speaker's threat or infers with his/her responsibilities. The threatener intentionally uses the threat to make the addressee complies with his/her threat. Thus, s/he aims to manipulate the addressee's behavior by displaying the intention of using negative consequences if the threat is refused. Performing such actions intensely influences the target's response. Yet, the threat is probable to fail in case the addressee thinks that the threatener is bluffing (Limberg, 2008, 2009).

There are conditional and non-conditional threats. The former refers to the speaker's restriction against the addressee and to the negative results that the speaker will impose on the addressee. As for non-conditional threats, the choice between accomplishing the speaker's demand and refusing the threat, but tolerating the expected consequences, requires a possible face loss. However, it depends on the context and the degree of power to decide which of the two options is less face-threatening (Limberg, 2009).

Verbal threats are hybrid verbs because of their linguistic and non-linguistic nature (Vanderveken, 1990). They are available in diverse linguistic forms, but none of them are fundamentally improper. That is to say, it is related to the decisions speakers make according to the social values of appropriateness. These values might differ with regard to three parameters: social, contextual, and cultural. Except for the social value of behavior, interlocutors' anticipations and interactional aims also affect speakers' decisions on a verbal strategy whether it is offensive, impolite, or something else. A case in point is that example: "If you don't move your car, I will have to give you a ticket." In this example, one may debate that the threat is proper due to two issues: the triggering action that the driver does by parking illegally and the 
authority the policeman has to reprimand the offensive behavior. Such a reaction in this presupposed context is socially and legally appropriate; yet, this speech act cannot be considered an ordinary form of performance in social interactions. It is attributed to the issue that it involves a face-aggravation as threats communicate social dissatisfaction and restrict hearers' action settings. The hearer must move his/her car at once or pay a fine due to the policeman's demand. This strategy can be assessed in a particular setting by inferring the hearer's response to the threat. If the threatened driver complies with the policeman, this means that s/he accepts the face attack, and if s/he rejects, the policeman performs an adverse reaction towards his/her face concerns. However, certain situations often stimulate aggressive responses from the target individual and sometimes cause an exacerbation of the conflict. This shows that the target understands the verbal threat as an impolite attack on his/her face (Limberg, 2009).

Impoliteness is a negative attitude towards specific behaviors caused by at least one individual (Kadhum \& Abbas, 2020). Judgments on impoliteness are affected by such social variables as power, distance, age, gender, and culture (Kuha, 2003). Power is frequently interrelated with politeness (Abbas, 2013) and impoliteness (Lakoff, 1989). It is a supportive means to confirm direct compliance but it is not always necessary for making a threat utterance successful (Limberg, 2009).

Brown and Levinson's (1987) theory of politeness paved the way for scholars to study the concept of impoliteness (Mohammed \& Abbas, 2016). As a result, Culpeper $(1996,2005)$ investigated impoliteness based on the theory mentioned above. Five strategies of impoliteness are proposed: 'bald on record impoliteness,' 'positive impoliteness,' 'negative impoliteness,' 'sarcasm or mock politeness,' and 'withhold politeness.' According to Limberg (2009), verbal threats had not been explicitly stated in Culpeper's list of strategies. They are associated with some of the output strategies, such as 'frighten,' 'emphasizing your relative power,' and 'invading the other's space,' and listed under 'negative impoliteness' (Culpeper, 1996). The conditional threats suggested by Limberg (2009) aim to manipulate the hearer's performance in that s/he is reluctantly obliged to conduct an action. These threats would associate with the output strategies proposed by Culpeper (1996), which are utilized to damage the hearers' negative face wants. Acting by force would restrict the hearer's freedom of action. In this case, threats do not only create a form of negative impoliteness, but rather they threaten the hearer's positive face wants via refusal, dislike, and shortage of understanding. Therefore, it is hard to categorize threats as an output strategy in the proposed framework of Culpeper (Limberg, 2009).

Limberg (2009) examined the threats from an impoliteness perspective. That is, impoliteness strategies are investigated in the addressees' responses to verbal threats in real-life situations. His framework is a revised version of Limberg's (2003) and Limberg and Geluykens's (2007) frameworks. A DCT is used and 1200 responses are collected from 212 English native speakers to examine the hearers' tendency in a particular conflict situation. The developed framework refers to the function and use of the reactions and the conflict performances of the addressees. The findings unveil that the participants mainly use 'toward compliance' or 'toward non-compliance' strategies. They tend to use the preferred responses more than the dispreferred responses. Besides, the participants' responses show a higher degree of 'compliance' and 'toward compliance' to threats produced by an individual of equal status. The categories do not show (im)polite values correlated with responses. Yet, the 'toward 
compliance' and 'compliance' categories indicate a face-saving quality while the 'toward noncompliance' and 'non-compliance' categories can be wholly face-threatening and dispreferred behavior.

Furthermore, interlocutors might produce mitigators to reduce the face threatening of their utterances. These mitigators are internal and external devices occurring in diverse speech acts such as request, apology, refusal, gratitude, etc. Likewise, the responses to threats can be mitigated by mitigators to modify the head act internally and externally. According to BlumKulka et al. (1989), the internal mitigators are either syntactic or lexical/phrasal devices occurring within the head act to mitigate it internally, while the external devices are supportive moves that can be used before and/or after the head act to modify it externally. EconomidouKogetsidis (2012, p. 191) revealed that "external modifiers tend to be syntactically less demanding and pragmalinguistically less complex as they usually involve the construction of a new, often syntactically simple clause." Hassall $(2001,2012)$ also shows the same remark when concluding similar results.

However, a great deal of studies investigated the offensive language in different genres such as media (Jan \& How, 2015), political talk (Al-Khazaali \& Al-Hindawi, 2016; GarciaPastor, 2008), legal discourse (Kuntsi, 2012), Facebook political discourse (Halim, 2015), military context (Culpeper, 1996), literary perspective (Rudanko, 2006), computer-mediated communication (Zhong, 2018), online football comments (Wibowo \& Kuntjara, 2012), and ESL/EFL context (Mugford, 2007). Moreover, several scholars investigated the concept of impoliteness in diverse languages such as British (Lucky, 2015), Japanese (Nishimura, 2010), English (Limberg, 2009), Malay (Alias \& Yahaya, 2019), Chinese (Zhong, 2018), Spanish (Marco, 2008), English and Arabic (Hammod \& Rassul, 2017), German (House, 2010), and Persian (Mirhosseini, Mardanshahi, \& Dowlatabadi, 2017).

Yet, Farnia and Sheibani (2019, p. 69) stated that "few studies have drawn their attention to the impoliteness in the threatening situations... In other words, few studies have investigated addressee's responses to verbal threats (e.g., Geluykens \& Limberg, 2012; Limberg, 2009)." Based upon this view, the current study fills a gap in pragmatics literature. It examines impoliteness in response to threatening situations in the Iraqi-Kurdish EFL context, which has not been conducted on particular research so far.

\section{Methods}

\section{Research Design}

Quantitative and qualitative data can be collected and analyzed in mixed-methods research design (Creswell, 2015). The current study uses mixed-methods research design. It integrates quantitative and qualitative approaches. The quantitative approach is represented by the DCT to collect the learners' responses and interpret them via descriptive statistics. The qualitative approach is used via the focus group interview to support the data analysis.

\section{Participants}

The current study is conducted on the Iraqi-Kurdish EFL context during October 2020. The participants are Kurds who are native speakers of Kurdish. They live in Koysinjaq district in Erbil governorate in the north of Iraq, the region of Iraqi Kurdistan. A random sampling method 
is used to select 50 Iraqi-Kurdish EFL learners (27 males and 23 females), ranging in age from 20 to 23 years. All of them are undergraduate university English learners at the Department of English, Faculty of Education, Koya University, Erbil, Iraq. They have not visited or lived in an English-speaking country before. They have participated voluntarily, and their names are kept confidential.

\section{Instruments}

The instruments of this study are used by the researcher via google classroom due to COVID 19. A background questionnaire is first given to the participants. This instrument is used in the form of a questionnaire written in English. It aims to elicit data about the participants' personal information such as age, gender, etc. (refer to Appendix A). Besides, the data of this study are collected by an open-ended questionnaire in the form of a Discourse Completion Task (DCT) (refer to Appendix B). Limberg's (2009) DCT is adapted to suit the context of the learners. This procedure is conducted after asking some learners about the salient threatening situations they always face in their daily life. They have stated that most of Limberg's scenarios are available in their context except for no. four changed to be between professor and student. Thus, the DCT includes six scenarios that are culturally specific in the Iraqi-Kurdish context. The scenarios involve a brief description of different situations written in English, followed by the threatener's threat, to which the learners are asked to respond. The social power of the speaker is dissimilar in these situations: higher, equal, and lower social power.

Moreover, these situations have been validated by experts in the context. Test-retest is applied to confirm the reliability result $(81 \%)$. The researcher has explained the aim of the study and the situations to the participants before conducting the DCT. The learners' responses are taken verbatim in this study. Besides, a focus group interview is conducted via google meet on another day to support the data analysis. The interview comprises specific questions related to the learners' responses to threatening situations.

\section{Data analysis}

The researcher has coded the data based on Limberg's (2009) model of impoliteness and threat responses, as illustrated in Table one. It involves five categories ('compliance,' 'toward compliance,' 'open-ended,' 'toward non-compliance,' and 'non-compliance'). Blum-Kulka et al.'s (1989) taxonomy of internal and external devices is adapted to analyze the mitigators, as shown in Table two. The internal devices are modifiers occurring within the head act to modify it internally. They involve syntactic downgraders (such as 'interrogative' and 'conditional clause') and lexical/phrasal downgraders (such as 'politeness marker' and 'appealer'). The external devices are supportive moves that occur before and/or after the head act to modify it externally, such as 'grounder,' 'promise,' and 'imposition minimizer.' The 'apology' mitigator is added to the external devices because it is unavailable in the original taxonomy. In addition, the data are analyzed quantitatively using descriptive statistics (i.e., frequency and percentage) to calculate the frequency of threatening responses. The researcher has consulted two inter-raters of pragmatics to code the data, and the reliability result is $83 \%$. 
Table 1. Description of threatening response categories

\begin{tabular}{|c|c|c|}
\hline \multicolumn{2}{|c|}{ Threatening Response Categories } & Description \\
\hline \multirow[b]{2}{*}{ Preferred } & Compliance & $\begin{array}{l}\text { "A response that signals the target's (purported) intention or willingness to } \\
\text { comply with threatener's demands will be taken as a form of compliance," e.g., } \\
\text { "Sorry, I'll move it for you." }\end{array}$ \\
\hline & $\begin{array}{l}\text { Toward } \\
\text { compliance }\end{array}$ & $\begin{array}{l}\text { "These utterances are not as explicit and straightforward in terms of the } \\
\text { speaker's response tendency as those instances in the C and NC category } \\
\text { because they often combine different strategies," e.g., "I don't think you } \\
\text { understand I'm extremly [sic] late but if you want me to move it's not a } \\
\text { problem." }\end{array}$ \\
\hline Open-ended & Open-ended & $\begin{array}{l}\text { "... is included to account for those instances that are openly interpretable in } \\
\text { terms of their illocutionary function and linguistic form," e.g., "Can I just park } \\
\text { here for just } 5 \text { minutes while I collect my parents, or is it absolutely necassary } \\
\text { [sic] for me to move?!" }\end{array}$ \\
\hline \multirow[t]{2}{*}{ Dispreferred } & $\begin{array}{c}\text { Toward } \\
\text { non-compliance }\end{array}$ & $\begin{array}{l}\text { "These utterances are not as explicit and straightforward in terms of the } \\
\text { speaker's response tendency as those instances in the C and NC category } \\
\text { because they often combine different strategies," e.g., "I'll only be a minute. } \\
\text { I'm late picking up my parents." }\end{array}$ \\
\hline & Non-compliance & $\begin{array}{l}\text { "A non-compliance response ... potentially resulting in an unsuccessful threat } \\
\text { which would then lead to further dispute," e.g., "Give a ticket then." }\end{array}$ \\
\hline
\end{tabular}

Note 1. Adopted from Limberg (2009, pp. 1385-1387)

Table 2. Taxonomy of mitigators

\begin{tabular}{|c|c|c|c|}
\hline \multicolumn{3}{|c|}{ Type of Mitigator } & Example \\
\hline \multirow{4}{*}{$\begin{array}{l}\text { Internal } \\
\text { Devices }\end{array}$} & \multirow{2}{*}{$\begin{array}{c}\text { Syntactic } \\
\text { Downgraders }\end{array}$} & Interrogative & "Is".../ “Will”... . \\
\hline & & Conditional Clause & "If you want it", ... \\
\hline & \multirow{2}{*}{$\begin{array}{l}\text { Lexical/phrasal } \\
\text { Downgraders }\end{array}$} & Politeness Marker & "Please"... \\
\hline & & Appealer & “Ok"... \\
\hline \multirow{4}{*}{$\begin{array}{c}\text { External } \\
\text { Devices }\end{array}$} & \multicolumn{2}{|c|}{ Grounder } & ...... "because I am too busy." \\
\hline & \multicolumn{2}{|c|}{\begin{tabular}{|l} 
Promise \\
\end{tabular}} & "I promise..." / "I will not do that." \\
\hline & \multirow{2}{*}{\multicolumn{2}{|c|}{$\begin{array}{c}\text { Imposition Minimizer } \\
\text { Apology }\end{array}$}} & ... "just for few minutes." \\
\hline & & & "I am sorry"/"I apologize." \\
\hline
\end{tabular}

Note 2. Adapted from Blum-Kulka et al. (1989, pp. 281-288)

\section{Results}

Table three indicates that the vast majority of Iraqi-Kurdish EFL learners prefer to use the 'compliance' strategy in situation one. $58 \%$ of the learners' corpus includes 'compliance' strategy while $30 \%$ and $12 \%$ of their corpus involve 'toward non-compliance' and 'towardcompliance' strategies, respectively. The learners avoid using 'open-ended' and 'noncompliance' strategies in this situation. As for situation four, these learners highly resort to the 'compliance' strategy (98\%) and sparingly use the 'open-ended' strategy (2\%). Other strategies such as 'toward-compliance,' 'toward non-compliance,' and 'non-compliance' have not been available in the learners' corpus. A closer look at the strategies used in situations one and four indicates that the most widely used strategy is 'compliance' (78\%), followed by 'toward non- 
compliance' (15\%), 'toward compliance' (6\%), and 'open-ended' (1\%) strategies. Overall, the whole amount of preferred responses outweighs those which show dispreference in each situation and across the two situations. The examples below illustrate the learners' responses in situations one and four where interlocutors have a higher social status:

Situation one:

"I am sorry officer, I will park my car somewhere else." ('Compliance')

"Please I need a minute because I am late to pick up my parents" ('Toward noncompliance')

"I will leave so soon after picking up my parents" ('Toward compliance')

Situation four:

"I understand I will take the exam and delay the family picnic to another day." ('Compliance')

"I will take the exam” ('Compliance')

"Can I postpone the exam or it is necessary?” ('Open-ended')

Table 3. Distribution of strategies in situations one \& four (higher social status)

\begin{tabular}{|c|c|c|c|c|c|c|c|c|c|c|}
\hline \multirow{2}{*}{\multicolumn{2}{|c|}{ Strategy }} & \multicolumn{2}{|c|}{ Situation 1} & & \multicolumn{2}{|c|}{ Situation 4} & & \multicolumn{3}{|c|}{ Situations $1 \& 4$} \\
\hline & & $\mathbf{F}$ & $\%$ & F \& (\%) & $\mathbf{F}$ & $\%$ & $F \&(\%)$ & $\mathbf{F}$ & $\%$ & F\& (\%) \\
\hline \multirow[b]{2}{*}{ Preferred } & Compliance & 29 & 58 & \multirow[b]{2}{*}{$35(70)$} & 49 & 98 & \multirow[b]{2}{*}{$49(98)$} & 78 & 78 & \multirow[b]{2}{*}{$84(84)$} \\
\hline & $\begin{array}{c}\text { Toward } \\
\text { compliance }\end{array}$ & 6 & 12 & & 0 & 0 & & 6 & 6 & \\
\hline \multicolumn{2}{|l|}{ Open-ended } & 0 & 0 & $0(0)$ & 1 & 2 & $1(2)$ & 1 & 1 & $1(1)$ \\
\hline \multirow[b]{2}{*}{ Dispreffered } & $\begin{array}{l}\text { Toward non- } \\
\text { compliance }\end{array}$ & 15 & 30 & \multirow[b]{2}{*}{$15(30)$} & 0 & 0 & \multirow[b]{2}{*}{$0(0)$} & 15 & 15 & \multirow[b]{2}{*}{$15(15)$} \\
\hline & $\begin{array}{c}\text { Non- } \\
\text { compliance }\end{array}$ & 0 & 0 & & 0 & 0 & & 0 & 0 & \\
\hline Total & & 50 & 100 & $50(100)$ & 50 & 100 & $50(100)$ & 100 & 100 & $\begin{array}{c}100 \\
(100)\end{array}$ \\
\hline
\end{tabular}

Table four illustrates that the 'toward compliance' strategy (54\%) is more frequently used by the learners in situation $2.28 \%$ of all responses comprises the 'toward non-compliance' strategy. In comparison, $10 \%$ and $8 \%$ involve 'compliance' and 'non-compliance' strategies respectively. As for the 'open-ended' strategy, it is quite avoided by the learners. The strategies used by the learners in situation five ranged from the most to the least common include 'toward compliance' (38\%), 'toward non-compliance' (28\%), 'compliance' (24\%), 'non-compliance' $(8 \%)$, and 'open-ended' (2\%). Overall, the learners mainly opt for the 'toward compliance' strategy $(46 \%)$ in situations two and five where the speakers have equal social status. They also use 'toward non-compliance' strategy (28\%) more frequently than 'compliance' (17\%), 'noncompliance' ( $8 \%$ ), and 'open-ended' (1\%) strategies. Importantly, these learners tend to use the preferred responses more often than the dispreferred ones in each situation and across the two situations. The examples below show the learners' strategies in situations two and five:

Situation two:

"Sorry, Ahmed but please if you want it, give me some more time." ("Toward compliance') 
"You are absolutely right and I apologize." ('Compliance')

"sorry l have no time." ('Non-compliance')

Situation five:

"because i am totally busy today, please do the cleaning and I will do your chores next time." ('Toward compliance')

"I am not the only one that live here I have lots of homework to do." ('Toward noncompliance')

"I will clean it quickly." ('Compliance')

Table 4. Distribution of strategies in situations two \& five (equal social status)

\begin{tabular}{|c|c|c|c|c|c|c|c|c|c|c|}
\hline \multirow{2}{*}{\multicolumn{2}{|c|}{ Strategy }} & \multicolumn{2}{|c|}{ Situation 2} & & \multicolumn{2}{|c|}{ Situation 5} & & \multicolumn{3}{|c|}{ Situations $2 \& 5$} \\
\hline & & $\mathbf{F}$ & $\%$ & F\& (\%) & $\mathbf{F}$ & $\%$ & F\& (\%) & $\mathbf{F}$ & $\%$ & $\begin{array}{l}\text { F\& } \\
(\%)\end{array}$ \\
\hline \multirow[b]{2}{*}{ Preferred } & Compliance & 5 & 10 & & 12 & 24 & \multirow[b]{2}{*}{$31(62)$} & 17 & 17 & \\
\hline & $\begin{array}{c}\text { Toward } \\
\text { compliance }\end{array}$ & 27 & 54 & $32(64)$ & 19 & 38 & & 46 & 46 & $\begin{array}{c}63 \\
(63)\end{array}$ \\
\hline \multicolumn{2}{|l|}{ Open-ended } & 0 & 0 & $0(0)$ & 1 & 2 & $1(2)$ & 1 & 1 & $1(1)$ \\
\hline \multirow[b]{2}{*}{ Dispreffered } & $\begin{array}{c}\text { Toward non- } \\
\text { compliance }\end{array}$ & 14 & 28 & & 14 & 28 & & 28 & 28 & \\
\hline & Non-compliance & 4 & 8 & $18(36)$ & 4 & 8 & $18(36)$ & 8 & 8 & $\begin{array}{c}36 \\
(36)\end{array}$ \\
\hline \multicolumn{2}{|c|}{ Total } & 50 & 100 & $50(100)$ & 50 & 100 & $50(100)$ & 100 & 100 & $\begin{array}{c}100 \\
(100)\end{array}$ \\
\hline
\end{tabular}

Table five indicates that 'toward non-compliance' strategy $(52 \%)$ is more frequently used in situation three, followed by 'non-compliance' (28\%), 'compliance' $(10 \%)$, 'toward compliance' ( $8 \%$ ), and 'open-ended' (2\%) strategies. The strategies used by these learners in situation six ranged from the most to the least common comprise 'toward compliance' (40\%), 'toward non-compliance' (36\%), 'compliance' (12\%), 'non-compliance' (10\%), and 'openended' $(2 \%)$. Overall, these learners have a tendency to use the 'toward non-compliance' strategy (44\%) more often than other strategies across situations three and six where the speakers have a lower social status. They also opt for 'toward compliance' strategy (24\%) more frequently than 'non-compliance' (19\%), 'compliance' (11\%), and 'open-ended' (2\%) strategies. While these learners tend to use the dispreferred responses more often than the preferred responses in situation three, they opt for the opposite in situation six. However, the total amount of dispreferred responses surpasses those which reveal preference across the two situations. The examples below demonstrate the learners' responses to the threatening situations three and six:

Situation three:

"Tell them and I will tell them you do bad things." ('Toward non-compliance')

"No problem tell them." ('Non-compliance')

"Please obey me and go to bed Adar, watching Tv for so long can be harmful for you"

('Non-compliance') 
"I will let you watch it for some time then you have to sleep." ('Compliance')

"I am sorry but I need to call my friend later I will allow you to watch it." (Toward compliance')

Situation six:

"You are right, but there is nothing wrong to the camera and I am sorry I take it without your permission I will not do that next time" ('Toward compliance')

"Actually you are not at home." ('Toward non-compliance')

"You are right $i$ had to ask your permission." ('Compliance')

"I am older than you and there is no need for permission." ('Non-compliance')

Table 5. Distribution of strategies in situations three \& six (lower social status)

\begin{tabular}{|c|c|c|c|c|c|c|c|c|c|c|}
\hline \multirow{2}{*}{\multicolumn{2}{|c|}{ Strategy }} & \multicolumn{2}{|c|}{ Situation 3} & & \multicolumn{2}{|c|}{ Situation 6} & & \multicolumn{3}{|c|}{ Situations 3 \& 6} \\
\hline & & $\mathbf{F}$ & $\%$ & F\& (\%) & $\mathbf{F}$ & $\%$ & F\& (\%) & $\mathbf{F}$ & $\%$ & $\begin{array}{l}\text { F\& } \\
(\%)\end{array}$ \\
\hline \multirow[b]{2}{*}{ Preferred } & Compliance & 5 & 10 & \multirow[b]{2}{*}{$9(18)$} & 6 & 12 & \multirow[b]{2}{*}{$26(52)$} & 11 & 11 & \\
\hline & $\begin{array}{c}\text { Toward } \\
\text { compliance }\end{array}$ & 4 & 8 & & 20 & 40 & & 24 & 24 & $35(35)$ \\
\hline \multicolumn{2}{|l|}{ Open-ended } & 1 & 2 & $1(2)$ & 1 & 2 & $1(2)$ & 2 & 2 & $2(2)$ \\
\hline \multirow{2}{*}{ Dispreffered } & $\begin{array}{l}\text { Toward non- } \\
\text { compliance }\end{array}$ & 26 & 52 & \multirow[b]{2}{*}{$40(80)$} & 18 & 36 & \multirow[b]{2}{*}{$23(46)$} & 44 & 44 & \multirow[b]{2}{*}{$63(63)$} \\
\hline & Non-compliance & 14 & 28 & & 5 & 10 & & 19 & 19 & \\
\hline \multicolumn{2}{|c|}{ Total } & 50 & 100 & $50(100)$ & 50 & 100 & $50(100)$ & 100 & 100 & $\begin{array}{c}100 \\
(100)\end{array}$ \\
\hline
\end{tabular}

Table six unveils that the vast majority of Iraqi-Kurdish EFL learners prefer to use the 'compliance' strategy (35\%) across all situations. Results also uncover that 'toward noncompliance' (29\%) and 'toward compliance' (25\%) strategies constitute an extent where these learners show salience while they less often use 'non-compliance' (9\%) and 'open-ended' (2\%) strategies. Overall, the preferred responses (61\%) surpass the dispreferred responses (38\%) across all situations.

Table 6. Distribution of strategies across all situations

\begin{tabular}{|c|c|c|c|c|c|}
\hline \multicolumn{2}{|r|}{ Strategy } & \multicolumn{2}{|c|}{ Situations } & \multicolumn{2}{|c|}{ Total } \\
\hline & & $\mathbf{F}$ & $\%$ & $\mathbf{F}$ & $\%$ \\
\hline \multirow[b]{2}{*}{ Preferred } & Compliance & 106 & 35 & & \\
\hline & Toward compliance & 76 & 25 & 182 & 61 \\
\hline \multicolumn{2}{|l|}{ Open-ended } & 4 & 2 & 4 & 1 \\
\hline \multirow{2}{*}{ Dispreffered } & Toward non-compliance & 87 & 29 & \multirow{2}{*}{114} & \multirow{2}{*}{38} \\
\hline & Non-compliance & 27 & 9 & & \\
\hline & Total & 300 & 100 & 300 & 100 \\
\hline
\end{tabular}


Furthermore, Table seven displays the types of mitigators used by Iraqi-Kurdish EFL learners across all situations. The 'grounder' (25\%) and 'apology' $(21 \%)$ are the most frequently used mitigators in the learners' responses. Other types of mitigators are used with various frequencies, such as $14 \%$ of all responses shows a tendency towards 'politeness marker,' $12 \%$ towards 'conditional clause,' and $11 \%$ towards 'promise.' The incidence of 'imposition minimizer' (7\%), 'interrogative' (5\%) and 'appealer' $(5 \%)$ is noticeably lower. Below are some examples of mitigators across all situations:

"Is (interrogative) it possible to stay for a while"

"Please (politeness marker) I need a minute because I am late to pick up my parents (grounder)",

"Ok (appealer) watch it, but just for few minutes (imposition minimizer)"

"Sorry, (apology) Ahmed but please (politeness marker) if you want it (conditional clause), give me some more time."

"I am sorry officer, (apology) I will park my car somewhere else."

"because $i$ am totally busy today, (grounder) please (politeness marker) do the cleaning and I will do your chores next time."

"You are right, but there is nothing wrong to the camera and I am sorry I take it without your permission (apology) I will not do that next time (promise)"

"Please (politeness marker) obey me and go to bed Adar, watching Tv for so long can be harmful for you (grounder)"

Table 7. Distribution of mitigators across all situations

\begin{tabular}{|c|c|c|c|c|}
\hline & Type of Mitigator & & F \& (\%) & $F \&(\%)$ \\
\hline \multirow{4}{*}{ Internal Devices } & & Interrogative & $10(5)$ & \multirow{4}{*}{$75(36)$} \\
\hline & & Conditional clause & $25(12)$ & \\
\hline & \multirow[t]{2}{*}{ Lexical/Phrasal Devices } & Politeness marker & $30(14)$ & \\
\hline & & Appealer & $10(5)$ & \\
\hline \multirow{4}{*}{ External Devices } & \multicolumn{2}{|c|}{ Grounder } & $53(25)$ & \multirow{4}{*}{$135(64)$} \\
\hline & \multirow{2}{*}{\multicolumn{2}{|c|}{$\begin{array}{c}\text { Promise } \\
\text { Imposition Minimizer }\end{array}$}} & $23(11)$ & \\
\hline & & & $15(7)$ & \\
\hline & \multicolumn{2}{|c|}{ Apology } & $44(21)$ & \\
\hline \multicolumn{3}{|c|}{ Total } & $210(100)$ & $210(100)$ \\
\hline
\end{tabular}

\section{Discussion}

Based on the results and the interview, it has been remarked that Iraqi-Kurdish EFL learners opt for 'compliance' strategy in situations one and four where the speaker is more potent than the hearer. The responses are more face-saving by the learners to comply with the threatener's demand which culturally indicate respect to the person who is higher in his/her social status. The verbal threats in these situations are legitimate and dynamic strategies to guarantee compliance from the addressee. That is quite true in the Iraqi-Kurdistan context where 
a policeman and a professor have authority and their demands should be complied with. The learners have decided to go along with the policeman's threat and use an apparent compliance. Most of them have stated that they can go to the parking area in order not to pay a fine and they can call their parents to pick them up soon. This reaction is clarified by Limberg (2009) in that the hearer accepts the face attack to avoid any negative consequences that could be performed by the threatener. Similarly, these learners comply with their professor's demand to take the exam because they can go with their family later on another day.

Besides, the 'toward non-compliance' strategy is more frequently used than the 'toward compliance' strategy by these learners in situation one. The diversity of responses, according to Farina and Sheibani (2019) and Limberg (2009), indicates that the learners have decided to either opt for an indirect refusal because they are mistreated by the policeman, or comply with the policeman's threat clearly. However, 'compliance' and 'toward non-compliance' strategies are favored by the learners across the two situations. In addition, the majority of the learners tend to use more preferred responses ('compliance' and 'toward compliance') than dispreferred responses ('toward non-compliance' and 'non-compliance') in each situation and across the two situations. In other words, they prefer to use more face-saving acts when receiving threats from individuals who are higher in their social status. This result is consistent with Farina and Sheibani's (2019) and Limberg's (2009) results because native English speakers produce more preferred responses than dispreferred ones in situations where interlocutors have a higher social status.

Results uncover that 'toward compliance' is the most salient strategy in situations two and five where interlocutors are equal in their status. Power is a significant social variable that influences the addressees' responses and their use of strategies. These learners do not like to escalate the conflict because their social relationship and mutual friendship are more important than trivial issues as proofreading a paper or cleaning the flat. Farina and Sheibani (2019) and Limberg (2009) have demonstrated that a friend mainly tends to comply with a threat produced by his/her well-acquainted friend to avoid conflict and keep their friendship. However, the learners opt for counterthreats and use 'toward non-compliance' as the second most often used strategy in their responses in both situations. It is clear that the learners' priority is to choose a face-saving strategy and comply with a friend's threat; yet, they opt for a face-threatening act when they find the threat offensive. They also tend to use the 'compliance' strategy because they understand that they should keep their promise in proofreading the paper and be committed to their duties when they share a flat with a friend. Overall, the preferred responses surpass the dispreferred ones due to the learners' tendency to use face-saving strategies in situations where interlocutors are equal in their social status. This result is congruent with Farina and Sheibani's (2019) result because Iranian EFL learners and English native speakers use more preferred responses than dispreferred ones in situations where the speakers have equal social status.

It is worth noting that the learners mostly use 'toward non-compliance' and 'noncompliance' strategies in situation three, which highlights the highest amount of counterthreats. This is attributed to the senior who opts for a face-threatening act because s/he is not more cooperative with a little kid. Besides, the learners have illustrated that they are elders and should be respected rather than threatened by a little niece. With regard to situation six, the learners mainly use the 'toward compliance' strategy and opt for a face-saving act because the younger 
brother is right. His camera is taken without his permission and it should be replaced if there is something wrong with it. Yet, the 'toward non-compliance' strategy is also preferred by the learners because the threat seems offensive from a younger brother. While the learners highly use dispreferred responses in situation three, they tend to use more preferred responses in situation six. This result is consistent with Limberg's (2009) result in the two situations mentioned above. The results also reveal that the learners tend to use the 'toward noncompliance' strategy across situations three and six. It constitutes an extent where Iraqi-Kurdish EFL learners show the most salience when they receive a threat from a junior who is supposed to respect their demands. Overall, the learners opt for a face-threatening act and their dispreferred responses surpass the preferred ones in situations where the threateners have a lower social status. This result agrees with Farina and Sheibani's (2019) and Limberg's (2009) results when the amount of the dispreferred responses surpasses the amount of the preferred ones by English native speakers in situations of lower social status.

Based on what is remarked, the overall results across all situations unveil that IraqiKurdish EFL learners rely primarily on the 'compliance' and 'toward non-compliance' strategies. This is due to their preference for either a face-saving act to comply with the threatener's threat and avoid any conflict or a face-threatening act to reject the threat indirectly. Besides, the 'toward compliance' strategy is also favored by the learners while the 'noncompliance' and 'open-ended' strategies are sparingly used. The latter is the least frequently used strategy in each situation and across all situations by these learners when they respond to threatening situations. This result is in line with Farina and Sheibani's (2019), Geluykens and Limberg's (2012), and Limberg's (2009) results which show that the 'open-ended' strategy is least frequently used by English native speakers and Iranian EFL learners. The total amount of the preferred responses is more frequent than the total amount of the dispreferred responses. This shows the learners' preference for face-saving acts when receiving threats in their context. This result is congruent with Farina and Sheibani's (2019), Geluykens and Limberg's (2012), and Limberg's (2009) overall results, which reveal that native speakers of English (and Iranian EFL learners) tend to use more preferred responses than dispreferred responses in the threatening situations.

Furthermore, Iraqi-Kurdish EFL learners tend to complement the head acts by internal and external devices to attenuate the illocutionary force of their responses, particularly the dispreferred ones. They tend to use more than one mitigator in one utterance to modify the head act of it. They resort to 'grounder' and 'apology' devices more than other types of mitigators. They prefer to provide reasons, explanation, and justification to convince the threatener of their responses and to downgrade their face-threatening acts. By doing so, they may reduce the aggressive tone of their indirect rejection when they do not comply with the threatener's demand. They also apologize when they do something unacceptable to avoid conflict with the threatener. This result agrees with Geluykens and Limberg's (2012) result which unveils that English native speakers tend to use more 'grounder' and 'apology' modifiers to mitigate the face attacks of their responses to threatening situations. On the other hand, 'politeness marker,' 'conditional clause,' 'interrogative,' 'appealer,' 'promise,' and 'imposition minimizer' are used with various frequencies by the learners. All of these mitigators downgrade the illocutionary force of their responses. 
However, these learners mainly resort to external devices that occur before and/or after the head acts more often than the internal devices in their responses. The external devices are easier in construction than the internal devices. The former include simple clauses whereas the latter are more difficult syntactically and pragmalinguistically. This is in line with EconomidouKogetsidis' (2012) and Hassall's $(2001,2012)$ results which unveil that learners tend to use more external modifiers than internal modifiers in their utterances.

\section{Conclusion}

One aspect of impoliteness that causes challenges in exchanges is face attack and the responses given to it. Threat acts do not only threaten the hearer's face but rather the speaker's face can also be damaged by verbal threats when the hearer deliberately does not comply with the speaker's threat or behaves aggressively. Responding to threats may create impoliteness if not performed appropriately. Thus, this study investigates how Iraqi-Kurdish EFL learners respond to offensive acts such as verbal threats performed intentionally in a conversation.

The findings unveil that the preferred responses surpass the dispreferred responses across all situations. Besides, 'compliance' is the most frequently used strategy by these learners across all situations. The second and third most commonly used strategies are 'toward non-compliance' and 'toward compliance.' They produce fewer 'non-compliance' responses and sparingly use an 'open-ended' strategy across all situations. The learners opt for a face-saving act when they comply with the threatener's demand, yet they resort to a face-threatening act to reject the threat in an indirect way when they find it offensive and aggressive. The findings reveal differences in using the strategies with a diversity of social power in diverse situations. There is evidence that these learners display some sensitivity towards the social power of the speaker. The data reveal that the preferred responses are favored in situations where the threateners are higher and equal in their social power. Yet, the dispreferred responses are mainly used in situations where the threateners have lower social power. Furthermore, these learners use mitigators, particularly 'grounder' and 'apology', to attenuate the illocutionary force of their responses. They use more external devices than internal devices in their reactions to threatening situations.

The results of the current study are advantageous to those who are interested in the context of EFL. It highlights impoliteness with threat responses which can be beneficial for EFL teachers and curriculum designers. It informs them how EFL learners behave and use the strategies and mitigators when they receive threats in their context. This study would improve EFL learners' pragmatic competence and raise EFL teachers' awareness of the social power in this issue. Moreover, curriculum designers can set up proper settings where strategies can be used for responding to aggressive utterances or face attacks. This study also suggests further studies to investigate the effect of age, gender, and culture on EFL learners when they respond to threatening occasions in their context.

\section{About the author:}

Shurooq Abboodi Ali earned her Ph.D. degree in Applied Linguistics/Pragmatics from University Sains Malaysia, Malaysia. She is currently an assistant professor of English linguistics at the College of Arts, University of Baghdad. Her areas of research include pragmatics, (critical) discourse analysis, and sociolinguistics.

ORCid ID: https://orcid.org/0000-0002-3641-6062 


\section{References}

Abbas, N. F. (2013). Positive politeness \& social harmony in literary discourse. International Journal of Applied Linguistics \& English Literature, 2(3), 186-195. Doi:10.7575/aiac.ijalel.v.2n.3p.186.

Al-Khazaali, M. \& Al-Hindawi, F. (2016). Impoliteness in political conflicts on terrorism. A model of pragmatic strategies in institutional debates. Deutschland: Lambert Academic Publishing.

Alias, A. \& Yahaya, M. Q. (2019). Impoliteness strategies used by Malaysia netizens in response to the music videos of dara queens. International Journal of Social Science Research, $1(2), 44-59$.

Austin, J. (1962). How to do things with words. Oxford: Oxford University Press.

Barron, A. (2003). Acquisition in interlanguage pragmatics. Learning how to do things with words in a study abroad context. Philadelphia, USA: John Benjamins Publishing Company.

Brown, P., \& Levinson, S. C. (1987). Politeness: Some universals in language usage. Cambridge: Cambridge University Press.

Blum-Kulka, S., House, J., \& Kasper, G. (1989). Cross-cultural pragmatics: Requests and apologies. Norwood, NJ: Ablex.

Creswell, J. W. (2015). Educational research: Planning, conducting, and evaluating quantitative and qualitative research (5th ed.). New York: Pearson.

Culpeper, J. (1996). Towards an anatomy of impoliteness. Journal of Pragmatics, 25(3), 349367. https://doi.org/10.1016/0378-2166(95)00014-3.

Culpeper, J. (2005). Impoliteness and entertainment in the television quiz show: The Weakest Link. Journal of Politeness Research 1, 35-72. DOI: 10.1515/jplr.2005.1.1.35.

Cutting, J. (2002). Pragmatics and discourse. A resource book for students. London: Routledge.

Economidou-Kogetsidis, M. (2012). Modifying oral requests in a foreign language: The case of Greek Cypriot learners of English. In M. Economidou-Kogetsidis \& H. Woodfield (Eds.), Interlanguage request modification (pp. 163-202). Philadelphia, USA: John Benjamins Publishing Company.

Fairclough, N. (1989). Language and power. London: Longman.

Farina, M. \& Sheibani, Z. (2019). Cross-cultural study of Iranian and English students' impoliteness and threat responses. The Journal of English Language Pedagogy and Practice, 12(24), 68-90. DOI: 10.30495/JAL.2019.671927.

Félix-Brasdefer, J. C. (2017). Interlanguage pragmatics. In Y. Huang (Ed.), The oxford handbook of pragmatics (pp. 416-434). Oxford: Oxford University Press.

Fraser, B. (1998). Threatening revisited. Forensic Linguistics (The International Journal of Speech, Language and the Law) 5(2), 159-173.

Garcia-Pastor, M. D. (2008). Political campaigns as zero-sum games: impoliteness and power in candidates' exchanges. In D. Bousfield \& M. A. Locher (Eds.), Impoliteness in Language: Studies on Its Interplay with Power in Theory and Practice (pp. 101-123). Berlin: Mouton de Gruyter.

Geluykens, R. \& Limberg, H. (2012). Gender variation, indirectness, and preference organization in threat responses. Rice Working Papers in Linguistics, 3, 1-12.

Halim, Sh. A. (2015). Impoliteness strategies used in a politician's Facebook. (Unpublished Master's thesis). University of Malaysia. 
Hammod, N. M. \& Rassul, A. A. (2017). Impoliteness strategies in English and Arabic Facebook comments. International Journal of Linguistics 9(5). DOI: 97-112. 10.5296/ijl.v9i5.11895.

Hanks, P. (2018). Types of speech acts. In D. Fogal, D. W. Harris, \& M. Moss (Eds.), New work on speech acts (pp. 123-143). Oxford: Oxford University Press.

Harris, S. (1984). The form and function of threats in court. Language \& Communication,4(4), 247-271. https://doi.org/10.1016/0271-5309(84)90010-7.

Hassall, T. (2001). Modifying requests in a second language. International Review of Applied Linguistics in Language Teaching, 39(4), 259-283. DOI: 10.1515/iral.2001.005.

Hassall, T. (2012). Request modification by Australian learners of Indonesian. In M. Economidou-Kogetsidis \& $\mathrm{H}$. Woodfield (Eds.), Interlanguage request modification (pp. 203-242). Philadelphia, USA: John Benjamins Publishing Company.

House, J. (2010). Impoliteness in Germany: Intercultural encounters in everyday and institutional talk. Intercultural Pragmatics, 7(4), 561-595.

Jan, J. M., \& How, C. (2015). Discursive construction of Asian responses towards impoliteness. Pertanika Journal of Social Sciences \& Humanities, 23(1), 89-106.

Kadhum, M. F. \& Abbas, N. F. (2020). Impoliteness in relation to You Tube: A pragmatic study. Proceedings of the first virtual scientific conference of the English Language Department in the College of Basic Education - Al-Mustansiriyah University in cooperation with the University alturath College, the Lebanese University and the Turkish University, Suleiman Admiral. Iraq. 105-123.

Kuha, M. (2003). Perceived seriousness of offense: the ignored extraneous variable. Journal of Pragmatics 35(12), 1803-1821. https://doi.org/10.1016/S0378-2166(03)00054-7.

Kuntsi, P. (2012). Politeness and impoliteness strategies used by lawyers in the 'Dover Trial' A case study, (Unpublished Master's thesis). University of Eastern Finland.

Lakoff, R. T. (1989). The limits of politeness: therapeutic and courtroom discourse. Multilingua $8(2 / 3), 101-129$.

Leech, G. N. (1983). Principles of pragmatics. London: Longman.

Limberg, H. (2003). Classifying threats and responses to threats: A sociopragmatic analysis, (Unpublished Master's Thesis). University of Muenster.

Limberg, H. (2008). Threats in conflict talk: impoliteness and manipulation. In: D. Bousfield \& M. A. Locher (Eds.). Impoliteness in language. Studies on its interplay with power in theory and practice (pp. 155-179). Berlin: Mouton de Gruyter.

Limberg, H. (2009). Impoliteness and threat responses. Journal of Pragmatics, 41(7), 13761394. https://doi.org/10.1016/j.pragma.2009.02.003.

Limberg, H., \& Geluykens, R. (2007). Investigating preference organization and social variation through questionnaires: the case of threat responses. In B. Kraft \& R. Geluykens (Eds.). Cross-Cultural pragmatics and interlanguage English (pp.159-185) München: Lincom Europa.

Lucky, J. (2015). A pragmatic analysis of impoliteness strategies in British TV-Series Sherlock, (Unpublished Master's thesis). Yogyakarta State University.

Marco, M. A. (2008). Influence of situational factors on the codification and interpretation of impoliteness. Pragmatics: Quarterly Publication of the International Pragmatics Association (IPrA), 18(4), 751-773. 
Mirhosseini, M., Mardanshahi, M., \& Dowlatabadi, H. (2017). Impoliteness Strategies Based on Culpeper's Model: An Analysis of Gender Differences between Two Characters in the movie Mother. Journal of Applied Linguistics and Language Research, 4(3). 221-238.

Mohammed, H. N. \& Abbas, N. F. (2016). Impoliteness in literary discourse: A pragmatic study. International Journal of Applied Linguistics \& English Literature, 5(2), 76-82. Doi:10.7575/aiac.ijalel.v.5n.2p.76.

Mugford, G. (2007). How rude! Teaching impoliteness in the second language classroom. ELT Journal, 62(4), 375-384. DOI: 10.1093/elt/ccm066.

Nishimura, Y. (2010). Impoliteness in Japanese BBS interactions: Observations from message exchanges in two online communities. Journal of Politeness Research: Language, Behaviour, Culture, 6(1), 35-55. DOI: 10.1515/JPLR.2010.003.

OED Online- Oxford English Dictionary. (2020). Oxford: Oxford University Press.

Pérez-Hernández, L. (2021). Speech acts in English. From research to instruction and textbook development. Cambridge: Cambridge University Press.

Rudanko, J. (2006). Aggravated impoliteness and two types of speaker intention in an episode in Shakespeare's Timons of Athens. Journal of Pragmatics 38(6), 829-841. https://doi.org/10.1016/j.pragma.2005.11.006.

Searle, J. R. (1969). Speech acts: An essay in the philosophy of language. Cambridge: Cambridge University Press.

Searle, J. R. (1979). Expression and meaning. Studies in the theory of speech acts. Cambridge: Cambridge University Press.

Schauer, G. A. (2009). Interlanguage pragmatic development: The study abroad context. London: Continuum International Publishing Group.

Storey, K. (1995). "The language of threats." Forensic Linguistics (The International Journal of Speech, Language and the Law) 2(1), 74-80.

Thomas, J. (1983). Cross-cultural pragmatic failure. Applied Linguistics, 4(2), 91-112. https://doi.org/10.1093/applin/4.2.91.

Vanderveken, D. (1990). Meaning and Speech Acts. Cambridge: Cambridge University Press.

Wibowo, G. \& Kuntjara, E. (2012). Impolitness strategies used on online comments in an Indonesian football website. K@ta Kita, 1(1). pp. 166-173.

Zhong, W. (2018). Linguistic impoliteness strategies in sina weibo comments. International Journal of Linguistics and Communication, 6(2), pp. 35-46. DOI: 10.15640/ijlc.v6n2a4.

Appendices

Appendix A

Background questionnaire

Native language: ................ .

Place of birth:

Country of citizenship:

Gender: Male ..... F Female ........ .

Age:

I am currently enrolled in:

Have you ever been to an English-speaking country? How long? 


\begin{tabular}{|c|c|c|}
\hline \multicolumn{3}{|c|}{$\begin{array}{c}\text { Appendix B } \\
\text { Description of DCT } \\
\end{array}$} \\
\hline $\begin{array}{l}\text { No. of } \\
\text { scenar } \\
\text { io }\end{array}$ & Situation description + threat utterance (in italics) & $\begin{array}{l}\text { Power } \\
\text { relation } \\
\quad \mathrm{S}\end{array}$ \\
\hline 1 & $\begin{array}{l}\text { You have to park your car in a non-parking area at the station because you're late to } \\
\text { pick up your parents. A policeman has watched you, comes up to you and says: "This } \\
\text { is a non-parking area where you have just parked. If you don't move your car, I'll have } \\
\text { to give you a ticket." }\end{array}$ & $\mathrm{S}>\mathrm{A}$ \\
\hline 2 & $\begin{array}{l}\text { Ahmed, a fellow student of yours, helps you out with your English homework and even } \\
\text { gets some former exam papers for you to practice. In return, you promised to help him } \\
\text { with the proofreading of his research paper, which you can't do for lack of time. When } \\
\text { you meet him, he says to you: "You were supposed to proofread my paper. If you don't } \\
\text { help me with my paper, you mustn't count on my help any longer.", }\end{array}$ & $\mathrm{S}=\mathrm{A}$ \\
\hline 3 & $\begin{array}{l}\text { You are taking care of your little niece Adar. Before she is allowed to watch TV in the } \\
\text { evening, she has to finish her homework. This takes a while; therefore you only let her } \\
\text { watch TV for a short time. Although it's not bedtime yet, you send her to bed because } \\
\text { she is becoming a nuisance and you want to call one of your friends for his/her } \\
\text { birthday. She says to you: "But I always get to watch the next show. If I'm not allowed } \\
\text { to watch TV any longer, I'll tell my parents.", }\end{array}$ & $\mathrm{S}<\mathrm{A}$ \\
\hline 4 & $\begin{array}{l}\text { You want to go on a picnic with your family on Wednesday. Your professor demands } \\
\text { you and your colleagues to take an exam on the same day you want to travel with your } \\
\text { family. Your professor says to you, "This is the only chance for you. If you do not take } \\
\text { the exam, your mark will be zero." }\end{array}$ & $\mathrm{S}>\mathrm{A}$ \\
\hline 5 & $\begin{array}{l}\text { You are sharing a flat with one of your fellow students. It is exam time and you have a } \\
\text { lot to study and less time to spend on other things such as cleaning the flat. Your fellow } \\
\text { student is fed up with you not doing your chores, so s/he says to you: "The bathroom is } \\
\text { still in a mess and it's your turn to clean it. If you are not cleaning up when's your duty, } \\
\text { you must do my chores next time.", }\end{array}$ & $\mathrm{S}=\mathrm{A}$ \\
\hline 6 & $\begin{array}{l}\text { Your little brother Shwan has been given a brand new digital camera for his birthday, a } \\
\text { present you have been keen on as well. One weekend you are going away with your } \\
\text { friends to the seaside and you would like to borrow your brother's camera. He is not at } \\
\text { home when you leave, so you take it without permission. When you return, he says to } \\
\text { you: 'I didn't allow you to take my new camera. If there's something wrong with the } \\
\text { camera, I want you to replace it.", }\end{array}$ & $\mathrm{S}<\mathrm{A}$ \\
\hline
\end{tabular}

